\title{
Cell cycle checkpoint in cancer: a therapeutically targetable double-edged sword
}

\author{
Roberta Visconti ${ }^{i^{*}}$, Rosa Della Monica ${ }^{2,3}$ and Domenico Grieco ${ }^{2,3^{*}}$
}

\begin{abstract}
Major currently used anticancer therapeutics either directly damage DNA or target and upset basic cell division mechanisms like DNA replication and chromosome segregation. These insults elicit activation of cell cycle checkpoints, safeguard mechanisms that cells implement to correctly complete cell cycle phases, repair damage or eventually commit suicide in case damage is unrepairable. Although cancer cells appear to be advantageously defective in some aspects of checkpoint physiology, recent acquisitions on the biochemical mechanisms of the various checkpoints are offering new therapeutic approaches against cancer. Indeed, chemical manipulation of these mechanisms is providing new therapeutic strategies and tools to increase the killing efficacy of major cancer therapeutics as well as to directly promote cancer cell death. In this review we summarize developing concepts on how targeting cell cycle checkpoints may provide substantial improvement to cancer therapy.
\end{abstract}

Keywords: Cell cycle checkpoint, Cancer drug, DNA damage, Mitosis, Chk1, Wee1, Spindle assembly checkpoint, Taxane, Vinca alkaloids, Fcp1

\section{Background}

The mechanisms of cell division and the genome itself are routinely endangered by endogenous and exogenous insults. For instance reactive oxygen species, produced during metabolic reactions, inflammation or exciting and ionizing radiations, can damage chromosomes and upset chromosome replication and segregation $[1,2]$. To avoid transmission of altered genome to daughter cells, elaborate checkpoint pathways have evolved to arrest cell cycle progression and promote repair or, in case of unrepairable damage, stimulate cell death. Cancer cells are often defective in these checkpoint mechanisms [3]. Such defects very likely contribute to neoplastic transformation and progression by coupling genetic instability with resistance to apoptotic cell death. Nevertheless, the actual information on checkpoint biochemistry and its deregulation in cancer, along with the development of relative pharmacologic tools, is now offering new

\footnotetext{
* Correspondence: r.visconti@ieos.cnr.it; domenico.grieco@unina.it

${ }^{1}$ IEOS, CNR, Via S. Pansini 5, 80131 Naples, Italy

2DMMBM, University of Naples "Federico II", Via S. Pansini 5, 80131 Naples,

Italy

Full list of author information is available at the end of the article
}

opportunities for cancer treatment. Here we will review how recent efforts to identify new strategies and drugs targeting cell cycle checkpoints will likely translate soon into benefit to clinical practice in oncology. As outlined in Table 1, we will focus our attention on drugs targeting key players of the $\mathrm{S}$ and $\mathrm{G} 2 / \mathrm{M}$ checkpoints activated in response to DNA damage and on drugs targeting the mitotic spindle assembly checkpoint (SAC). For more details on other regulators of the DNA damage response, including microRNAs and long-non coding RNAs, and on their small molecule inhibitors the readers may refer to other publications [4-8].

\section{G1-S, S and G2/M checkpoints}

The overall cellular response to damaged DNA, known as DNA damage response (DDR), is composed of sensor proteins that detect and signal DNA damage to downstream effectors that, in turn, arrest cell cycle progression and promote repair. In response to DNA damage, cell cycle checkpoints can be activated in G1 phase, in S phase and at the $\mathrm{G} 2 / \mathrm{M}$ transition $[9,10]$. In particular, the Ataxia Telangiectasia Mutated (ATM) kinase is activated by DNA double strand breaks (DSBs) and triggers the G1 
Table 1 Cell cycle checkpoint targeting drugs

\begin{tabular}{cll}
\hline Target & Drug & References \\
\hline S and G2/M checkpoint targeting drugs & \\
Chk1/2 & UCN-01 & {$[35,37-40]$} \\
& ICP-1 & {$[36]$} \\
& PF00477736 & {$[41,42]$} \\
& XL9844 & {$[43]$} \\
& PD321852 & {$[44]$} \\
& CEP3891 & {$[45]$} \\
& AZD7762 & {$[46]$} \\
& LY2603618 & {$[47]$} \\
& Gö6976 & {$[48]$} \\
& SCH900776 (MK-8776) & {$[49,50,53]$} \\
& CCT244747 & {$[51]$} \\
ATR & NU6027 & {$[54]$} \\
Wee1 & MK-1775 & {$[55-65]$} \\
Spindle assembly checkpoint targeting drugs & \\
Microtubular $\beta$-tubulin & Taxanes, Vinca alkaloids & {$[68,77]$} \\
Wee1 & MK-1775 & {$[92]$} \\
\hline
\end{tabular}

checkpoint by phosphorylating and activating the Checkpoint Kinase 2 (Chk2) [11]. Chk2 inhibits Cdc25A, a phosphatase that removes inhibitory phosphorylation of the cyclin A/Cyclin-dependent kinase (Cdk)2 and cyclin E/Cdk2 complexes, preventing cells from proceeding into $\mathrm{S}$ phase [12]. Of note, the G1 checkpoint is critically dependent on p53. In addition, ATM induces phosphorylation of p53, reducing its affinity for the negative regulator, the ubiquitin ligase $\mathrm{Mdm} 2$, leading to p53 stabilization [13-15]. Stabilized p53 induces p21, that binds and further inhibits cyclin A/Cdk2 and cyclin E/Cdk2 complexes, DNA repair proteins and, upon protracted checkpoint activation, apoptotic cell death promoters [16-20].

When DNA damage occurs in $\mathrm{S}$ phase, arising from stalled replication forks, nucleotide excision/repair process or as intermediates of DSB resolution, the intra S phase checkpoint is activated to prevent further replication $[21,22]$. The damage is sensed by the Ataxia Telangiectasia and Rad3-related (ATR) kinase that, by activating Checkpoint Kinase 1 (Chk1), induces Cdc25A proteosomal degradation, blocking further progression through $\mathrm{S}$ phase $[23,24]$. ATR and Chk1 also trigger the G2/M checkpoint, which prevents cells with damaged DNA from entering mitosis. Mitosis onset requires activity of the master mitotic kinase cyclin B-dependent kinase 1 (Cdk1) [25]. Cdk1 catalytic activity is inhibited during the $\mathrm{S}$ and G2 phases through the phosphorylation on T14 and Y15 induced by the kinases Wee1 and Myt1 [26, 27]. These phosphorylations are removed at the G2/M transition by the Cdc25C phosphatase [26]. To prevent cells with damaged DNA from entering mitosis, ATR inhibits cyclin
B/Cdk1 activation by stimulating the Cdk1 inhibitory kinase Wee1 and inhibiting Cdc25C via Chk1 [28, 29].

In response to DNA damage ATM and ATR not only stop cell cycle progression but also initiate DNA repair by phosphorylating several other substrates. If damage cannot be repaired, the cell destiny might be death or permanent growth arrest (senescence) [30, 31]. When cells with irreparable DNA damage are forced to enter into mitosis, they undergo permanent growth arrest or cell death through a so-called mitotic catastrophe mechanism. Although the mitotic catastrophe mechanistic details are still unclear, it has been recently proposed as an oncosuppressive mechanism, initiated during the $\mathrm{M}$ phase and requiring a prolonged mitotic arrest. Mitotic catastrophe results either in cells dying in mitosis or in cells reaching the subsequent $\mathrm{G} 1$ phase of the cell cycle and then dying or undergoing senescence. It is unclear whether mitotic catastrophe kills the cells by apoptosis, necrosis or autophagy; however, likely it is the result of simultaneous activation or sequential triggering of different cell death-inducing pathways [32]. These observations suggest that forced entry of DNA-damaged cells into mitosis may provide a substantial increase in therapeutic efficacy.

Damaging DNA with either chemo- or radiotherapy is the most frequently used strategy for treating human cancer; however, collateral DNA damage to normal cells, particularly in highly proliferative tissues, often limits clinical efficacy. Recently, starting from the observation that cancer cells that have defective checkpoints, often because of $\mathrm{p} 53$ pathway mutations, can still stop the cell cycle and avoid DNA damage-induced cell death by relying on the other checkpoint branches [33], a novel anticancer therapeutic strategy has begun to develop. This is based on combining DNA damaging drugs with drugs targeting the Chk $1 / 2$ pathways to force cancer cells to bypass the $S$ and G2/M arrest and enter mitosis with DNA damage, leading to mitotic catastrophe [32, 34].

Many specific Chk1 inhibitors have been developed, that showed promising results in preclinical studies. UCN-01 and its analog ICP-1 have mostly shown efficacy in combination with drugs inducing replication stress such as the DNA cross-linker cisplatinum and the topoisomerase I targeting drugs, suggesting that the intra-S-phase checkpoint bypass is indeed a key step to chemotherapy sensitization $[35,36]$. Phase I trials with the Chk1 inhibitor UCN-01 in combination with cisplatinum provided important proof of principle that a Chk1 inhibitor prevented cell cycle arrest caused by cisplatinum-induced DNA damage [37, 38]. Indeed, in cisplatinum-treated patients, UCN-01 infusion caused a drastic reduction of geminin, a biomarker of DNA damage-induced cell cycle arrest, as detected by immunohistochemistry in tumor biopsies [38]. However, phase II clinical trials with UCN-01 
have been discontinued, mostly because of low target specificity and unfavorable pharmacokinetics [39, 40]. Many other Chk1 inhibitors have been developed and tested proving efficacy alone and in combination with other genotoxic drugs in preclinical settings [41-45]; however, the few tested in Phase I and Phase II trials have shown severe side effects and none or limited efficacy [46, 47]. Thus, many second-generation Chk1 inhibitors have recently been developed [48-51]. Preclinical studies have shown that second-generation Chk1 inhibitors are effective if used in combination with DNA-damaging drugs [48, 49]. Moreover, they are greatly effective at sensitizing cells to antimetabolites such as cytarabine or the pyrimidine antagonist gemcitabine $[49,50,52]$. These compounds, once metabolized, are incorporated into DNA, causing strand termination. Moreover, gemcitabine inhibits ribonucleotide reductase, thus depleting dNTP pool and inhibiting DNA synthesis. As Chk1 is required to stabilize the stalled replication forks, it is hypothesized that the second-generation Chk1 inhibitors cause replication fork collapse and DNA double strand breaks. Recently the phase I clinical trial results of the second generation Chk1 inhibitor SCH900776 in association with antimetabolite drugs have been reported showing promising, preliminary evidence of clinical activity in small groups of patients [50, 53]. SCH900776 is currently undergoing testing in a phase II trial in association with cytarabine in adult leukemia patients.

To target the $\mathrm{S}$ and G2/M checkpoint, a potent, selective ATR inhibitor, NU6027, has been developed and preclinical studies in breast and ovarian carcinoma cell lines show promising results. NU6027, in fact, was not cytotoxic as single agent; however, the drug acted to sensitize tumor cells to a variety of genotoxic insults, including ionizing radiation, cisplatinum and doxorubicin, among others [54].

Wee1 is a crucial kinase that prevents the onset of mitosis in cells that have incompletely replicated or have damaged genomes. In case of DNA damage, ATR-activated Wee1 arrests the cells at the G2/M checkpoint, allowing time for repair [28]. A Wee1 small-molecule inhibitor, MK-1775, a pyraxolo-pyrimidine derivative, is already available for oral administration and several preclinical studies have demonstrated its potency and selectivity for Wee1 (with an $\mathrm{IC}_{50}$ of $5 \mathrm{nmol} / \mathrm{L}$ ) [55]. MK-1775, by abrogating the G2/M checkpoint, allows cells with damaged DNA to progress into mitosis, leading to mitotic catastrophe. Thus, most of the preclinical studies have tested MK1775 in combination with DNA damaging drugs. Indeed, MK-1775 has been shown to synergize with a wide variety of DNA damaging agents (such as radiation [56], the topoisomerase inhibitor doxorubicin [57], the anti-metabolite 5-fluorouracil [57], the DNA cross-linker cisplatinum [55]). As expected, MK-1775 cytotoxicity was more pronounced in p53 minus, G1 checkpoint-deficient cells that are strictly dependent on the G2/M checkpoint to avoid mitotic entry with DNA damage and, in turn, death [55-57]. Xenograft studies in nude mice bearing cervical, ovarian, colorectal, lung, glial and pancreatic cancers have demonstrated that oral administration of MK-1775 in combination with several DNA damaging agents induces tumor regression $[55,56,58,59]$. Phase I trials testing MK-1775 in combination with DNA damaging drugs have shown promising results, as the toxicity was easily manageable. Currently several phase II trials are underway [60].

Besides its key role in the G2/M checkpoint, Wee1 kinase controls proper timing of mitosis onset by performing inhibitory phosphorylation of Cdk1 [26]. Accordingly, using sarcoma cell lines and patient-derived tumor explants, it has been demonstrated that MK-1775, by inducing premature mitosis entry, has cytotoxic effects even when utilized as single agent [61]. On the basis of the Wee1 role in mitosis entry regulation, a novel therapeutic regimen has been suggested by combining MK-1775 with gemcitabine that, as discussed before, by targeting ribonucleotide reductase, depletes dNTP pool, thus inhibiting DNA synthesis. MK-1775 forced gemcitabine-arrested cells into mitosis without completing S-phase thereby resulting in extensive DNA damage, micronuclei formation and ultimately apoptotic death [62].

Of note, it has been demonstrated that Wee1 also regulates initiation and progression of DNA replication forks, preventing DNA double strand breaks during replication [63]. Thus, it has been suggested that MK-1775 might kill the cells by inducing DNA double stand breaks as a consequence of deregulated DNA replication rather than premature mitosis [64]. Accordingly, MK-1775 cytotoxicity does not correlate with the mitotic indexes of several cancer cell lines [64].

Irrespective of the controversial mechanism, a phase I single agent study of MK-1775 in patients with advanced solid tumors has been carried out to assess safety, tolerability and pharmacokinetics of the drug [65]. The only reported dose-limiting toxicities were supraventricular tachyarrhythmia and myelosuppression. Of twenty-five enrolled patients, two carrying BRCA mutations (one with head and neck cancer and one with ovarian cancer) showed partial responses. The trial has also evaluated the MK-1775 effects on pY15-Cdk1 (reduction in two of five paired tumor tissue biopsies) and on DNA damage markers (increase in $\gamma \mathrm{H} 2 \mathrm{AX}$ levels in three of five tumor tissue paired biopsies). The results indicated that MK-1775 induced stalled replication forks and DNA double strand breaks.

\section{The spindle assembly checkpoint}

In mitosis, correct partitioning of replicated genome is granted by a safeguard mechanism, called Spindle Assembly Checkpoint (SAC), that prevents errors in chromosome segregation by delaying progression into anaphase 
until mitotic spindle assembly completion. SAC inhibits the ubiquitin ligase anaphase-promoting complex/ cyclosome $(\mathrm{APC} / \mathrm{C})$ and delays degradation of cyclin $\mathrm{B}$ and of the anaphase inhibitor securin until bipolar attachment of all chromosome pairs [66]. SAC is imposed by the recruitment to unattached or tensionless kinetochores (the proteinaceous centromeric structures that interact with spindle microtubules) of the Mitotic Checkpoint Complex (MCC). MCC is composed by the proteins BubR1, Bub3 and Mad2 associated with the essential APC/C coactivator Cdc20 [67]. SAC is activated by taxanes (Paclitaxel, Docetaxel, etc.) and vinca alkaloids (Vinblastine, Vincristine, etc.), which are among the most widely used anticancer drugs. These drugs are referred to as anti-microtubule cancer drugs (AMCDs). They bind $\beta$-tubulin and affect microtubule dynamics and mitotic spindle assembly. The taxanes stabilize preexisting microtubules, while the vinca alkaloids prevent microtubule polymerization [68]. Thus, in their presence, malformed or incomplete spindles activate the SAC. Cells held in mitosis by AMCDs-induced SAC undergo apoptosis after prolonged mitotic duration [69]. Although Cdk1 phosphorylates and inhibits caspase 9 (thereby protecting against apoptosis during normal mitosis), caspase 9 ultimately becomes dephosphorylated upon prolonged arrest in mitosis [70]. In addition, it has been demonstrated that prolonged activity of cyclin $\mathrm{B} / \mathrm{Cdk} 1$ causes degradation of the antiapoptotic protein Mcl1, leading to caspase-dependent cell death of AMCDs-treated cells [71]. Moreover, Cdk1 has a role in the inhibition of the anti-apoptotic proteins $\mathrm{Bcl}-\mathrm{X}_{\mathrm{L}}$ and $\mathrm{Bcl}-2$ [72, 73]. Thus, the SAC arrest-dependent apoptosis induced by AMCDs provides a mechanistic rationale for the therapeutic use of these drugs. However, cancer cells can also slip through mitosis, despite malformed spindles, by adapting to the SAC. Slippage occurs because, despite an active SAC, cyclin B is slowly degraded to levels below that needed to sustain Cdk1 activity and the mitotic state [74]. A recently developed model suggests that proapoptotic signals accumulate during AMCDs-induced prolonged mitosis; however, cells can survive the treatment if they slip through mitosis before a certain proapoptotic signal threshold has been reached [75]. Conversely, if the threshold is reached before slippage, cells die [75, 76]. Most of the cells that slip through mitosis either stop dividing in a tetraploid G1 state, become senescent, or die at later stages [76]. Nevertheless, a small fraction of slipped cancer cells, especially if p53-negative, may continue dividing, thus, resisting the treatment and generating further aneuploidy via aberrant mitosis $[75,76]$. By generating higher genomic instability rates, this process predisposes, in principle, cells to the acquisition of a more malignant phenotype (development of metastatic capability, drug resistance, etc.). Thus, mitotic slippage is believed a crucial mechanism for the development of resistance to AMCDs, in addition to the first described enhanced activity of MDR efflux pumps [69, 75-77]. AMCDs clinical benefits are curtailed not only by resistance but also by significant, dose-limiting, collateral damage $[68,78]$. The most relevant side effects are neutropenia, consequence of toxicity on hematopoietic precursor cells, and peripheral neuropathy, due to the critical role of microtubules in neuronal axoplasmic transport [68]. To circumvent side effects, in particular peripheral neuropathy, new strategies to arrest mitotic progression without directly affecting microtubule physiology have been implemented. Indeed, a new class of drugs targeting kinesin motor proteins, that are crucially required for bipolar spindle assembly, are currently under clinical trials. It is noteworthy, however, that to date the clinical trials for this novel mitosistargeting drugs have not confirmed the promising effects seen in preclinical models as single agents [79-83]. As an additional strategy to target mitosis, a large number of molecules has been developed and evaluated to inhibit Plk1, Aurora A and Aurora B kinases as their inactivation results in gross aneuploidy, by lack of chromosome segregation, and eventual cell death [84-86]. Nevertheless, initial clinical trials with Plk and Aurora inhibitors have not confirmed the promising preclinical data [87]. Therefore, the actual improvement in cancer cell killing efficiency of several, new mitosis-targeting compounds still wait to be established [79, 87]. Thus, novel therapeutic regimens, perhaps combining AMCDs with other drugs that prevent mitotic slippage, are needed to improve cancer cell killing efficiency helping to limit resistance occurrence and reduce side effects.

\section{A novel combined therapy targeting SAC-induced arrest in mitosis}

Besides side effects and resistance, AMCDs are still among the most successful anti-tumor drugs, validating mitotic spindle as an excellent target for cancer chemotherapy. Thus, much effort has been directed to developing novel inroads that target spindle assembly and dynamics to improve AMCDs efficacy. A novel mitosis-targeting therapeutic approach is here proposed, based on our recent findings on mechanisms regulating mitosis exit and the SAC. We recently unveiled a novel, transcriptionindependent, crucial role for the essential RNA polymerase II-carboxy-terminal domain phosphatase Fcp1 in bring about Cdk1 inactivation at the end of mitosis [88-90]. We identified cyclin B degradation pathway components, like $\mathrm{Cdc} 20$ and the deubiquitinating enzyme USP44, and the Cdk1 inhibitory kinase Wee1 as crucial Fcp1 targets. At mitosis exit, Fcp1 promoted inhibitory Cdk1 phosphorylation by dephosphorylating Wee1, and ubiquitindependent cyclin B degradation by dephosphorylating Cdc20 and USP44. This lead us to hypothesize that, 
during prolonged mitosis in AMCDs-treated cancer cells, progressive Fcp1-induced Wee1 reactivation might lead to progressive loss of Cdk1 activity that weakens the SAC to a point in which the mitotic state could not be sustained [91]. This will translate into mitotic slippage, survival and AMCDs-resistance. Indeed, we validated this hypothesis by demonstrating that, in AMCDs-treated cells, SAC slippage depends on Fcp1-Wee1-Cdk1 (FWC). In Paclitaxel- or Vincristine-treated cells, in fact, progressive Fcp1-dependent Wee1 dephosphorylation lead to Cdk1 inactivation, SAC slippage and mitotic exit [92]. Remarkably, siRNA down modulation of Fcp1 or Wee1 significantly delayed slippage and mitotic exit in AMCDstreated cells. Moreover, the anti-apoptotic Mcl1 protein levels were reduced to a minimum and apoptotic cell death was substantially augmented. Thus, inhibiting the FWC axis can sustain the SAC-dependent mitotic delay induced by AMCDs, substantially delaying slippage and increasing AMCDs therapeutic efficacy. Wee1 is inhibitable by orally available drugs such as MK-1775; therefore our data present a rational framework for testing the therapeutic efficiency of AMCDs in combination with Wee1 inhibitors. Indeed, we have shown that MK-1775 treatment greatly enhanced mitotic arrest, Mcl1 degradation and caspase-dependent apoptosis in several Paclitaxel-treated cell lines as well as in Vincristine- treated primary lymphoblastic leukemia cells [92]. Moreover, we predict that the combination MK-1775 plus AMCDs may allow substantial reduction of AMCDs dosage. This approach may also reduce collateral damage in patients without loosing overall AMCDs therapeutic efficacy. Therefore, the observation that the FWC axis plays a critical role in SAC slippage and mitotic exit in AMCDstreated cancer cells provides a strong rationale for the use of MK-1775 in combination with AMCDs.

\section{Conclusions}

DNA- and mitotic spindle-damaging drugs still remain mainstream in cancer therapy. However, it has become progressively clear that cancer cells have defective cell cycle checkpoints. These defects, which very likely contribute to neoplastic transformation and progression by increasing genetic instability, can be exploited to envision strategies that will increase our armoury against cancer.

As recapitulated in Fig. 1 and extensively discussed in the review, Chk1/2, ATR or Wee1 inhibitors can sensitize cancer cells to DNA damaging drugs forcing the cells with DNA damage to bypass the $S$ and G2/M arrest and enter mitosis, leading to cell death by mitotic catastrophe. Strong preclinical evidences for the use of checkpoint targeting drugs alone or in combination with standard radio and/or chemotherapy have been accumulating during the
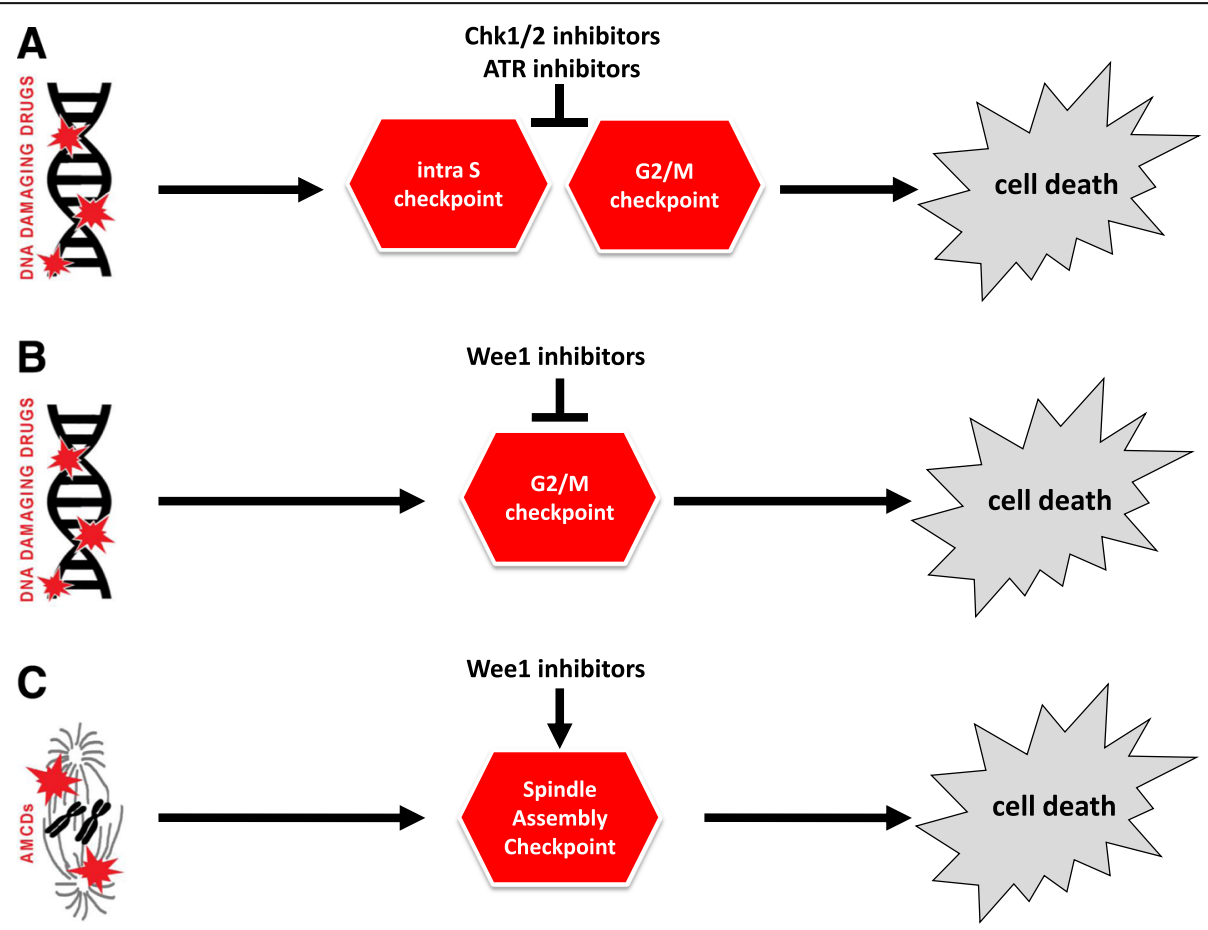

Fig. 1 Targeting the cell cycle checkpoints in cancer. a Chk1/2 or ATR inhibitors in combination with DNA damaging drugs forces cancer cells with DNA damage to bypass the $S$ and G2/M checkpoint arrest and enter mitosis, leading to cell death. $\mathbf{b}$ Wee1 inhibitors in combination with DNA damaging drugs forces cancer cells with DNA damage to bypass the G2/M checkpoint arrest and progress into mitosis, leading to cell death. c Wee1 inhibitors sustain the SAC-dependent mitotic delay induced by AMCDs, substantially increasing AMCDs therapeutic efficacy 
recent years. It has to be noticed, however, that many Phase I trials have been terminated for toxicity and/or low target specificity, or merely for business reasons. Few Phase I trials, though, do have helped in selecting the drugs well tolerated and with some preliminary clinical efficacy. Thus, now we eagerly wait for the results of the ongoing Phase II trials.

As an alternative approach to the challenging testing of new drugs alone or in combination with standard therapy, we have here proposed the combinatory use of two already clinically usable drugs, the Wee1 inhibitor MK-1775 and AMCDs, on the basis of the novel role we unveiled for Wee1 in regulating mitosis exit. Our preclinical studies have demonstrated that MK-1775 limits AMCDs resistance; moreover, we predict that MK-1775 will allow substantial dosage reduction of AMCDs, decreasing their side effects. By suggesting that Wee1 inhibitors could be beneficial in combination with AMCDs, our data may further expand our options for cancer treatment. In particular, we hypothesize that the association of Wee1 inhibitors with AMCDs could be potentially beneficial in several cases, in which AMCDs are used as monotherapeutic agents as, for instance, in second line therapeutic regimens for several hematological and solid tumors.

\section{Abbreviations \\ AMCDs: Anti-microtubule cancer drugs; APC/C: Anaphase-promoting complex/cyclosome; ATM: Ataxia telangiectasia mutated; ATR: Ataxia telangiectasia and Rad3-related; Cdk: Cyclin-dependent kinase; Chk: Checkpoint kinase; DDR: DNA damage response; DSBs: Double strand breaks; FWC: Fcp1-Wee1-Cdk1; MCC: Mitotic checkpoint complex; SAC: Spindle assembly checkpoint}

\section{Acknowledgements}

Not applicable.

\section{Funding}

This work has been supported by a grant from AIRC, Associazione Italiana per la Ricerca sul Cancro, to D.G. (grant number IG15476).

\section{Authors' contributions}

RV and DG are the corresponding authors, searched the literature and drafted the manuscript. RV, RDM, DG participated in the discussion, provided conceptual input, read and approved the final manuscript.

\section{Competing interest}

The authors declare that they have no competing interest.

\section{Declarations section}

Not applicable.

\section{Author details}

${ }^{1}$ IEOS, CNR, Via S. Pansini 5, 80131 Naples, Italy. ${ }^{2}$ DMMBM, University of Naples "Federico II", Via S. Pansini 5, 80131 Naples, Italy. ${ }^{3}$ CEINGE Biotecnologie Avanzate, Via G. Salvatore 486, 80145 Naples, Italy.

Received: 30 June 2016 Accepted: 20 September 2016 Published online: 27 September 2016

\section{References}

1. Jackson SP, Bartek J. The DNA-damage response in human biology and disease. Nature. 2009;461:1071-8.
2. Visconti R, Grieco D. New insights on oxidative stress in cancer. Curr Opin Drug Discov Devel. 2009;12:240-5.

3. Curtin NJ. DNA repair dysregulation from cancer driver to therapeutic target. Nat Rev Cancer. 2012;12:801-17.

4. Hunter T, Pines J. Cyclins and cancer. II: Cyclin D and CDK inhibitors come of age. Cell. 1994;79:573-82.

5. Sherr CJ. Cancer cell cycles. Science. 1996;274:1672-7.

6. Wan G, Mathur R, Hu X, Zhang X, Lu X. miRNA response to DNA damage. Trends Biochem Sci. 2011;36:478-84.

7. Mathur R, Chandna S, N Kapoor P, S Dwarakanath B. Peptidyl prolyl isomerase, Pin 1 is a potential target for enhancing the therapeutic efficacy of etoposide. Curr Cancer Drug Targets. 2011;11:380-92.

8. Wan G, Mathur R, Hu X, Liu Y, Zhang X, Peng G, Lu X. Long non-coding RNA ANRIL (CDKN2B-AS) is induced by the ATM-E2F1 signaling pathway. Cell Signal. 2013;25:1086-95.

9. Kastan MB, Bartek J. Cell-cycle checkpoints and cancer. Nature. 2004;432:316-23.

10. Bartek J, Lukas J. DNA damage checkpoint: from initiation to recovery or adaptation. Curr Opin Cell Biol. 2007;19:238-45.

11. Matsuoka S, Huang M, Elledge SJ. Linkage of ATM to cell cycle regulation by the Chk2 protein kinase. Science. 1998;282:1893-7.

12. Falck J, Mailand N, Syljuåsen RG, Bartek J, Lukas J. The ATM-Chk2-Cdc25A checkpoint pathway guards against radioresistant DNA synthesis. Nature. 2001;410:842-7.

13. Shieh SY, Ikeda M, Taya Y, Prives C. DNA damage-induced phosphorylation of p53 alleviates inhibition by MDM2. Cell. 1997;91:325-34.

14. Banin S, Moyal L, Shieh S, Taya Y, Anderson CW, Chessa L, Smorodinsky NI, Prives C, Reiss Y, Shiloh Y, Ziv Y. Enhanced phosphorylation of p53 by ATM in response to DNA damage. Science. 1998;281:1674-7.

15. Canman CE, Lim DS, Cimprich KA, Taya Y, Tamai K, Sakaguchi K, Appella E, Kastan MB, Siliciano JD. Activation of the ATM kinase by ionizing radiation and phosphorylation of p53. Science. 1998;281:1677-9.

16. Harper JW, Adami GR, Wei N, Keyomarsi K, Elledge SJ. The p21 Cdk-interacting protein Cip1 is a potent inhibitor of G1 cyclin-dependent kinases. Cell. 1993:75:805-16.

17. el-Deiry WS, Tokino T, Velculescu VE, Levy DB, Parsons R, Trent JM, Lin D, Mercer WE, Kinzler KW, Vogelstein B. WAF1, a potential mediator of p53 tumor suppression. Cell. 1993;75:817-25.

18. Gu Y, Turck CW, Morgan DO. Inhibition of CDK2 activity in vivo by an associated 20 K regulatory subunit. Nature. 1993;366:707-10.

19. Vousden KH, Lu X. Live or let die: The cell's response to p53. Nat Rev Cancer. 2002;2:594-604.

20. Soddu S, Sacchi A. P53 role in DNA repair and tumorigenesis. J Exp Clin Cancer Res. 1997;16:237-42.

21. Errico A, Costanzo V. Mechanisms of replication fork protection: a safeguard for genome stability. Crit Rev Biochem Mol Biol. 2012;47:222-35.

22. Cimprich KA. Probing ATR, activation with model DNA templates. Cell Cycle. 2007;6:2348-54

23. Mailand N, Falck J, Lukas C, Syljuasen RG, Welcker M, Bartek J, Lukas J. Rapid destruction of human Cdc25A in response to DNA damage. Science. 2000;288:1425-9.

24. Xiao Z, Chen Z, Gunasekera AH, Sowin TJ, Rosenberg SH, Fesik S, Zhang H. Chk1 mediates $S$ and $\mathrm{G} 2$ arrests through Cdc25A degradation in response to DNA-damaging agents. J Biol Chem. 2003;278:21767-73.

25. Nigg EA. Mitotic kinases as regulators of cell division and its checkpoints. Nat Rev Mol Cell Biol. 2001:2:21-32.

26. Parker LL, Piwnica-Worms H. Inactivation of the p34cdc2-cyclin B complex by the human WEE1 tyrosine kinase. Science. 1992;257:1955-7.

27. Booher RN, Holman PS, Fattaey A. Human Myt1 is a cell cycle-regulated kinase that inhibits Cdc2 but not Cdk2 activity. J Biol Chem. 1997;272:22300-6.

28. O'Connell M, Raleigh J, Verkade H, Nurse P. Chk1 is a wee1 kinase in the G2 DNA damage checkpoint inhibiting cdc2 by Y15 phosphorylation. EMBO J. 1997; 16:545-54

29. Sanchez Y, Wong C, Thoma RS, Richman R, Wu Z, Piwnica-Worms H, Elledge $\mathrm{SJ}$. Conservation of the Chk1 checkpoint pathway in mammals: linkage of DNA damage to Cdk regulation through Cdc25. Science. 1997;277:1497-501.

30. Shiloh Y, Ziv Y. The ATM protein kinase: regulating the cellular response to genotoxic stress, and more. Nat Rev Mol Cell Biol. 2013;14:197-210.

31. Cimprich KA, Cortez D. ATR: an essential regulator of genome integrity. Nat Rev Mol Cell Biol. 2008;9:616-27.

32. Vitale I, Galluzzi L, Castedo M, Kroemer G. Mitotic catastrophe: a mechanism for avoiding genomic instability. Nat Rev Mol Cell Biol. 2011;12:385-92. 
33. Allday MJ, Inman GJ, Crawford DH, Farrell PJ. DNA damage in human B cells can induce apoptosis, proceeding from G1/S when p53 is transactivation competent and G2/M when it is transactivation defective. EMBO J. 1995;14:4994-5005.

34. Chen T, Stephens PA, Middleton FK, Curtin NJ. Targeting the S and G2 checkpoint to treat cancer. Drug Discov Today. 2012;17:194-202.

35. Bunch RT, Eastman A. Enhancement of cisplatin-induced cytotoxicity by 7-hydroxystaurosporine (UCN-01), a new G2-checkpoint inhibitor. Clin Cancer Res. 1996;2:791-7.

36. Eastman A, Kohn EA, Brown MK, Rathman J, Livingstone M, Blank DH, Gribble GW. A novel indolocarbazole, ICP-1, abrogates DNA damage-induced cell cycle arrest and enhances cytotoxicity: similarities and differences to the cell cycle checkpoint abrogator UCN-01. Mol Cancer Ther. 2002;1:1067-78.

37. Lara Jr PN, Mack PC, Synold T, Frankel P, Longmate J, Gumerlock PH, Doroshow JH, Gandara DR. The cyclin-dependent kinase inhibitor UCN-01 plus cisplatin in advanced solid tumors: a California cancer consortium phase I pharmacokinetic and molecular correlative trial. Clin Cancer Res. 2005; 11:4444-50

38. Perez RP, Lewis LD, Beelen AP, Olszanski AJ, Johnston N, Rhodes $\mathrm{CH}_{\text {, }}$ Beaulieu B, Ernstoff MS, Eastman A. Modulation of cell cycle progression in human tumors: a pharmacokinetic and tumor molecular pharmacodynamic study of cisplatin plus the Chk1 inhibitor UCN-01 (NSC 638850). Clin Cancer Res. 2006;12:7079-85.

39. Li T, Christensen SD, Frankel PH, Margolin KA, Agarwala SS, Luu T, Mack PC, Lara Jr PN, Gandara DR. A phase II study of cell cycle inhibitor UCN-01 in patients with metastatic melanoma: a California Cancer Consortium trial. Invest New Drugs. 2012;30:741-8.

40. Ma CX, Ellis MJ, Petroni GR, Guo Z, Cai SR, Ryan CE, Craig Lockhart A, Naughton MJ, Pluard TJ, Brenin CM, Picus J, Creekmore AN, Mwandoro T, Yarde ER, Reed J, Ebbert M, Bernard PS, Watson M, Doyle LA, Dancey J, Piwnica-Worms H, Fracasso PM. A phase II study of UCN-01 in combination with irinotecan in patients with metastatic triple negative breast cancer. Breast Cancer Res Treat. 2013;137:483-92.

41. Blasina A, Hallin J, Chen E, Arango ME, Kraynov E, Register J, Grant S, Ninkovic S, Chen P, Nichols T, O'Connor P, Anderes K. Breaching the DNA damage checkpoint via PF-00477736, a novel small-molecule inhibitor of checkpoint kinase 1. Mol Cancer Ther. 2008;7:2394-404.

42. Chilà R, Basana A, Lupi M, Guffanti F, Gaudio E, Rinaldi A, Cascione L, Restelli V, Tarantelli C, Bertoni F, Damia G, Carrassa L. Combined inhibition of Chk1 and Wee1 as a new therapeutic strategy for mantle cell lymphoma. Oncotarget. 2015;6:3394-408.

43. Matthews DJ, Yakes FM, Chen J, Tadano M, Bornheim L, Clary DO, Tai A, Wagner JM, Miller N, Kim YD, Robertson S, Murray L, Karnitz LM. Pharmacological abrogation of S-phase checkpoint enhances the anti-tumor activity of gemcitabine in vivo. Cell Cycle. 2007;6:104-10.

44. Parsels LA, Morgan MA, Tanska DM, Parsels JD, Palmer BD, Booth RJ, Denny WA, Canman CE, Kraker AJ, Lawrence TS, Maybaum J. Gemcitabine sensitization by checkpoint kinase 1 inhibition correlates with inhibition of a Rad51 DNA damage response in pancreatic cancer cells. Mol Cancer Ther. 2009:8:45-54.

45. Syljuåsen RG, Sørensen CS, Nylandsted J, Lukas C, Lukas J, Bartek J. Inhibition of Chk1 by CEP-3891 accelerates mitotic nuclear fragmentation in response to ionizing radiation. Cancer Res. 2004;64:9035-40.

46. Sausville E, Lorusso P, Carducci M, Carter J, Quinn MF, Malburg L, Azad N, Cosgrove D, Knight R, Barker P, Zabludoff S, Agbo F, Oakes P, Senderowicz A. Phase I dose-escalation study of AZD7762, a checkpoint kinase inhibitor, in combination with gemcitabine in US patients with advanced solid tumors. Cancer Chemother Pharmacol. 2014;73:539-49.

47. Scagliotti G, Kang JH, Smith D, Rosenberg R, Park K, Kim SW, Su WC, Boyd TE, Richards DA, Novello S, Hynes SM, Myrand SP, Lin J, Smyth EN, Wijayawardana S, Lin AB, Pinder-Schenck M. Phase II evaluation of LY2603618, a first-generation CHK1 inhibitor, in combination with pemetrexed in patients with advanced or metastatic non-small cell lung cancer. Invest New Drugs. 2016;34:625-35.

48. Thompson R, Meuth M, Woll P, Zhu Y, Danson S. Treatment with the Chk1 inhibitor Gö6976 enhances cisplatin cytotoxicity in SCLC cells. Int J Oncol. 2012;40:194-202.

49. Montano R, Chung I, Garner KM, Parry D, Eastman A. Preclinical development of the novel Chk1 inhibitor SCH900776 in combination with DNA-damaging agents and antimetabolites. Mol Cancer Ther. 2012;11:427-38.

50. Daud Al, Ashworth MT, Strosberg J, Goldman JW, Mendelson D, Springett G, Venook AP, Loechner S, Rosen LS, Shanahan F, Parry D, Shumway S,
Grabowsky JA, Freshwater T, Sorge C, Kang SP, Isaacs R, Munster PN. Phase I dose-escalation trial of checkpoint kinase 1 inhibitor MK-8776 as monotherapy and in combination with gemcitabine in patients with advanced solid tumors. J Clin Oncol. 2015;33:1060-6.

51. Walton MI, Eve PD, Hayes A, Valenti MR, De Haven Brandon AK, Box G, Hallsworth A, Smith EL, Boxall KJ, Lainchbury M, Matthews TP, Jamin Y, Robinson SP, Aherne GW, Reader JC, Chesler L, Raynaud FI, Eccles SA, Collins I, Garrett MD. CCT244747 is a novel potent and selective CHK1 inhibitor with oral efficacy alone and in combination with genotoxic anticancer drugs. Clin Cancer Res. 2012;18:5650-61.

52. Sakurikar N, Eastman A. Will targeting Chk1 have a role in the future of cancer therapy? J Clin Oncol. 2015;33:1075-7.

53. Karp JE, Thomas BM, Greer JM, Sorge C, Gore SD, Pratz KW, Smith BD, Flatten KS, Peterson K, Schneider P, Mackey K, Freshwater T, Levis MJ, McDevitt MA, Carraway HE, Gladstone DE, Showel MM, Loechner S, Parry DA Horowitz JA, Isaacs R, Kaufmann SH. Phase I and pharmacologic trial of cytosine arabinoside with the selective checkpoint 1 inhibitor Sch 900776 in refractory acute leukemias. Clin Cancer Res. 2012;18:6723-31.

54. Peasland A, Wang LZ, Rowling E, Kyle S, Chen T, Hopkins A, Cliby WA, Sarkaria J, Beale G, Edmondson RJ, Curtin NJ. Identification and evaluation of a potent novel ATR inhibitor, NU6027, in breast and ovarian cancer cell lines. Br J Cancer. 2011;105:372-81.

55. Hirai H, Iwasawa Y, Okada M, Arai T, Nishibata T, Kobayashi M, Kimura T, Kaneko N, Ohtani J, Yamanaka K, Itadani H, Takahashi-Suzuki I, Fukasawa K, Oki H, Nambu T, Jiang J, Sakai T, Arakawa H, Sakamoto T, Sagara T, Yoshizumi T, Mizuarai S, Kotani H. Small-molecule inhibition of Wee1 kinase by MK-1775 selectively sensitizes p53-deficient tumor cells to DNA-damaging agents. Mol Cancer Ther. 2009:8:2992-3000.

56. Bridges KA, Hirai H, Buser CA, Brooks C, Liu H, Buchholz TA, Molkentine JM, Mason KA, Meyn RE. MK-1775, a novel Wee1 kinase inhibitor, radiosensitizes p53-defective human tumor cells. Clin Cancer Res. 2011;17:5638-48.

57. Hirai H, Arai T, Okada M, Nishibata T, Kobayashi M, Sakai N, Imagaki K, Ohtani J, Sakai T, Yoshizumi T, Mizuarai S, Iwasawa Y, Kotani H. MK-1775, a small molecule Wee1 inhibitor, enhances anti-tumor efficacy of various DNAdamaging agents, including 5-fluorouracil. Cancer Biol Ther. 2010;9:514-22.

58. Caretti $V$, Hiddingh $L$, Lagerweij $T$, Schellen $P$, Koken PW, Hulleman E, van Vuurden DG, Vandertop WP, Kaspers GJ, Noske DP, Wurdinger T. WEE1 kinase inhibition enhances the radiation response of diffuse intrinsic pontine gliomas. Mol Cancer Ther. 2013;12:141-50.

59. Rajeshkumar NV, De Oliveira E, Ottenhof N, Watters J, Brooks D, Demuth T, Shumway SD, Mizuarai S, Hirai H, Maitra A, Hidalgo M. MK-1775, a potent Wee1 inhibitor, synergizes with gemcitabine to achieve tumor regressions, selectively in p53-deficient pancreatic cancer xenografts. Clin Cancer Res. 2011;17:2799-806.

60. Do K, Doroshow JH, Kummar S. Wee1 kinase as a target for cancer therapy. Cell Cycle. 2013;12:3159-64.

61. Kreahling JM, Gemmer JY, Reed D, Letson D, Bui M, Altiok S. MK1775, a selective Wee1 inhibitor, shows single-agent antitumor activity against sarcoma cells. Mol Cancer Ther. 2012;11:174-82.

62. Aarts M, Sharpe R, Garcia-Murillas I, Gevensleben H, Hurd MS, Shumway SD, Toniatti C, Ashworth A, Turner NC. Forced mitotic entry of S-phase cells as a therapeutic strategy induced by inhibition of WEE1. Cancer Discov. 2012;2:524-39.

63. Beck H, Nähse-Kumpf V, Larsen MS, O'Hanlon KA, Patzke S, Holmberg C, Mejlvang J, Groth A, Nielsen O, Syljuåsen RG, Sørensen CS. Cyclin-dependent kinase suppression by WEE1 kinase protects the genome through control of replication initiation and nucleotide consumption. Mol Cell Biol. 2012;32:4226-36.

64. Guertin AD, Li J, Liu Y, Hurd MS, Schuller AG, Long B, Hirsch HA, Feldman I, Benita Y, Toniatti C, Zawel L, Fawell SE, Gilliland DG, Shumway SD. Preclinical evaluation of the WEE1 inhibitor MK-1775 as single-agent anticancer therapy. Mol Cancer Ther. 2013;12:1442-52.

65. Do K, Wilsker D, Ji J, Zlott J, Freshwater T, Kinders RJ, Collins J, Chen AP, Doroshow JH, Kummar S. Phase I study of single-agent AZD1775 (MK-1775), a Wee1 kinase inhibitor, in patients with refractory solid tumors. J Clin Oncol. 2015:33:3409-15.

66. Musacchio A, Salmon ED. The spindle-assembly checkpoint in space and time. Nat Rev Mol Cell Biol. 2007;8:379-93.

67. Sudakin V, Chan GK, Yen TJ. Checkpoint inhibition of the APC/C in HeLa cells is mediated by a complex of BUBR1, BUB3, CDC20, and MAD2. J Cell Biol. 2001;154:925-36.

68. Zhou J, Giannakakou P. Targeting microtubules for cancer chemotherapy. Curr Med Chem Anticancer Agents. 2005;5:65-71. 
69. Rieder CL, Maiato H. Stuck in division or passing through: what happens when cells cannot satisfy the spindle assembly checkpoint. Dev Cell. 2004;7:637-51.

70. Allan LA, Clarke PR. Phosphorylation of caspase-9 by CDK1/cyclin B1 protects mitotic cells against apoptosis. Mol Cell. 2007;26:301-10.

71. Harley ME, Allan LA, Sanderson HS, Clarke PR. Phosphorylation of Mcl-1 by CDK1-cyclin B1 initiates its Cdc20-dependent destruction during mitotic arrest. EMBO J. 2010;29:2407-20.

72. Sakurikar N, Eichhorn JM, Alford SE, Chambers TC. Identification of a mitotic death signature in cancer cell lines. Cancer Lett. 2014;343:232-8.

73. Zhou L, Cai X, Han X, Xu N, Chang DC. CDK1 switches mitotic arrest to apoptosis by phosphorylating $\mathrm{BCl}-2 / \mathrm{Bax}$ family proteins during treatment with microtubule interfering agents. Cell Biol Int. 2014;38:737-46.

74. Brito DA, Rieder CL. Mitotic checkpoint slippage in humans occurs via cyclin B destruction in the presence of an active checkpoint. Curr Biol. 2006;16:1194-200.

75. Topham CH, Taylor SS. Mitosis and apoptosis: how is the balance set? Curr Opin Cell Biol. 2013;25:780-5.

76. Gascoigne KE, Taylor SS. How do anti-mitotic drugs kill cancer cells? J Cell Sci. 2009;122:2579-85.

77. Horwitz SB, Cohen D, Rao S, Ringel I, Shen HJ, Yang CP. Taxol: mechanisms of action and resistance. J Natl Cancer Inst Monogr. 1993;15:55-61.

78. Kadoyama K, Kuwahara A, Yamamori M, Brown JB, Sakaeda T, Okuno Y. Hypersensitivity reactions to anticancer agents: data mining of the public version of the FDA adverse event reporting system, AERS. J Exp Clin Cancer Res. 2009;28:130

79. Chan KS, Koh CG, Li HY. Mitosis-targeted anti-cancer therapies: where they stand. Cell Death Dis. 2012;3, e411.

80. Mayer TU, Kapoor TM, Haggarty SJ, King RW, Schreiber SL, Mitchison TJ. Small molecule inhibitor of mitotic spindle bipolarity identified in a phenotype-based screen. Science. 1999;286:971-4.

81. Duhl DM, Renhowe PA. Inhibitors of kinesin motor proteins-research and clinical progress. Curr Opin Drug Discov Devel. 2005;8:431-6.

82. El-Nassan HB. Advances in the discovery of kinesin spindle protein (Eg5) inhibitors as antitumor agents. Eur J Med Chem. 2013;62:614-31.

83. Wang J, Cui F, Wang X, Xue Y, Chen J, Yu Y, Lu H, Zhang M, Tang H, Peng Z. Elevated kinesin family member $26 \mathrm{~B}$ is a prognostic biomarker and a potential therapeutic target for colorectal cancer. J Exp Clin Cancer Res. 2015:34:13.

84. Zhang Y, Liu Y, Yang YX, Xia JH, Zhang HX, Li HB, Yu CZ. The expression of PLK-1 in cervical carcinoma: a possible target for enhancing chemosensitivity. J Exp Clin Cancer Res. 2009;28:130.

85. Wu X, Liu W, Cao Q, Chen C, Chen Z, Xu Z, Li W, Liu F, Yao X. Inhibition of Aurora B by CCT137690 sensitizes colorectal cells to radiotherapy. J Exp Clin Cancer Res. 2014;33:13.

86. Lens SM, Voest EE, Medema RH. Shared and separate functions of polo-like kinases and aurora kinases in cancer. Nat Rev Cancer. 2010;10:825-41.

87. Aart M, Linardopoulos S, Turner NC. Tumour selective targeting of cell cycle kinases for cancer treatment. Curr Opin Pharmacol. 2013;13:529-35.

88. Visconti R, Palazzo L, Della Monica R, Grieco D. Fcp1-dependent dephosphorylation is required for M-phase-promoting factor inactivation at mitosis exit. Nat Commun. 2012;3:894.

89. Visconti R, Palazzo L, Pepe A, Della Monica R, Grieco D. The end of mitosis from a phosphatase perspective. Cell Cycle. 2013;12:17-9.

90. Della Monica R, Visconti R, Cervone N, Serpico AF, Grieco D. Fcp1 phosphatase controls Greatwall kinase to promote PP2A-B55 activation and mitotic progression. Elife. 2015;4, e10399.

91. D'Angiolella V, Mari C, Nocera D, Rametti L, Grieco D. The spindle checkpoint requires cyclin-dependent kinase activity. Genes Dev. 2003;17:2520-5.

92. Visconti R, Della Monica R, Palazzo L, D'Alessio F, Raia M, Improta S, Villa MR, Del Vecchio L, Grieco D. The Fcp1-Wee1-Cdk1 axis affects spindle assembly checkpoint robustness and sensitivity to antimicrotubule cancer drugs. Cell Death Differ. 2015:22:1551-60.

\section{Submit your next manuscript to BioMed Central and we will help you at every step:}

- We accept pre-submission inquiries

- Our selector tool helps you to find the most relevant journal

- We provide round the clock customer support

- Convenient online submission

- Thorough peer review

- Inclusion in PubMed and all major indexing services

- Maximum visibility for your research

Submit your manuscript at www.biomedcentral.com/submit
Biomed Central 